\title{
BIOLOGICAL REMEDIATION OF AMMONIA IN THE RIVER NILE BY USING EFFICIENT BACILLUS ISOLATES UNDER STATIC CULTURE CONDITIONS
}

\author{
Shalaby, M. E. ${ }^{1}$ - El-KhateEb, N. M. M. ${ }^{1}$-EL-Gremi, Sh.M. ${ }^{1}$ - El-SAYEd, I. E..$^{2 *}$ \\ ${ }^{1}$ Agricultural Botany Dept., (Agric. Microbiology), Fac. of Agric., Kafrelsheikh Univ. \\ Kafr El-sheikh, Egypt \\ ${ }^{2}$ Water and Wastewater Company, Main laboratory of Sidi Salem city, Kafr El-sheikh, Egypt \\ ${ }^{*}$ Corresponding author \\ e-mail: Ibrahimelsayedahmed@yahoo.com
}

(Received $8^{\text {th }}$ Aug 2019; accepted $25^{\text {th }}$ Nov 2019)

\begin{abstract}
Applicability of ammonia bioremediation by efficient bacterial isolates was investigated under static batch culture conditions. Bacillus aerius (M.1), Bacillus bingmayongensis (M.2) and Bacillus toyonensis (M.3) were isolated from the Inlet of El-Bahr El-Saedy drinking water treatment plant, Rosetta Branch, Egypt and identified based on their morphological, cultural and biochemical characteristics. Identification of these isolates via genomic 16S rRNA sequencing technique was also performed. To optimize ammonia removing process, effect of some environmental conditions $(\mathrm{pH}$, temperature and ammonia concentrations) were tested. Results indicated that a $\mathrm{pH}$ of 6.5 and 7.0, and the temperature between 30 and $35^{\circ} \mathrm{C}$ were the most optimal values for removing ammonia by the three tested isolates. Ammonia was consumed effectively during the first five incubation days, indicating maximum consumption rate, but it was reduced to its lowest level 25 days after incubation. Ammonia consumption rates were increased by increasing its concentration for all tested isolates, indicating growth activation and no substrate inhibition. Ammonia consumption rate by the ternary mixture reached its maximum of $1.60 \mathrm{mg} \mathrm{L}^{-1} \mathrm{day}^{-1}$ five days after incubation, and then reduced slowly to $0.38 \mathrm{mg} \mathrm{L}^{-}$ ${ }^{1}$ day $^{-1} 25$ days after incubation. It indicated sequential and synergistic effects between the isolates in their ternary mixture during the removal of ammonia.
\end{abstract}

Keywords: aquatic system, bacillus isolates, consumption rate, genomic sequences, pollution

\section{Introduction}

Nile River is the main source of fresh water used for drinking, agricultural activities, industry, navigation, recreation and fish production in Egypt. So, it is of dominating influence on the economic, cultural, public health, social and political aspects of the country (Ibrahim et al., 2018). Nile receives enormous amounts of environmental pollutants including fertilizers, fishing activities, pesticides and great amounts of industrial wastes, municipal and domestic materials which drained directly or indirectly into it. Due to their limitation, fresh water resources worldwide required more attention, especially in Egypt, to overcome the harmful effects of such pollutions against all vital activities. Nile pollutants are derived from sources such as industrial wastewater, oil pollution, municipal wastewater and agricultural drainage (Abou-Elela et al., 2017). The pollution status of the water of Nile River is an important indicator of water quality (Ibrahim et al., 2018). In this aspect AbdelSatar et al. (2017) reported that the problem of Nile pollution will increase in Egypt, if Nile's low water level was done; especially after completing the Ethiopia Dam building.

The cost needed for environmental degradation due to water pollution is relatively high with serious health and quality of life consequences; as well as increasing the severity of water scarcity problems (Zenhom et al., 2017). Hence, increasing water pollution causes not only the deterioration of water quality, but also threatens human health and the balance of 
aquatic ecosystems, economic development and social prosperity (Fawzy et al., 2012). Nitrogen is one of the most common element appearing in wastewater as ammonia, nitrite, nitrate and organic nitrogen. Organic nitrogen is decomposed to ammonia which has effects on human health (Nieder et al., 2018). Ammonia is a common pollutant in Nile River where it increases in winter because of the winter block which causes low water levels and the leaching of fertilizer residues used on the agriculture into the aquatic environment (AlRashedy et al., 2018). The maximum acceptable concentration of ammonia in the drinking water is equal to $0.5 \mathrm{mg} / \mathrm{dm}^{3}$ according to WHO Guidelines for drinking water and Egyptian standards (WHO, 2006). Bioremediation of ammonia using microorganisms shows great potential for future development due to its environmental compatibility and possible cost-effectiveness (Belal et al., 2017). Microorganisms, such as Burkhulderia cepacia $\mathrm{G} 4$, are effectively used in bioremediation processes due to their natural capacity to oxidize toxic hazardous substances such as phenol and benzoate as a sole source of carbon (Shalaby, 2007). Chemosynthetic autotrophic bacteria, Ammonia Oxidizing Bacteria (AOB) and Nitrite Oxidizing Bacteria (NOB) can convert ammonia to nitrate, and heterotrophic bacteria converts ammonia directly to microbial biomass. Microbes like chemolitho-autotrophic bacteria converts ammonia into nitrite and nitrates. These nitrates are again converted to nitrogen gas by denitrification process (Holmes et al., 2019).

Therefore, this study was carried out to isolate and identify some ammonia-degrading bacterial isolates from the Nile River and to evaluate their substrate consumption rates at different ammonia concentrations from the aquatic samples. As well as, ability of the tested bacterial isolates to remove ammonia at different levels of $\mathrm{pH}$, temperature and ammonia concentrations was also aimed to be described. As well as, removing of ammonia by a ternary mixture of isolates was also evaluated under static batch culture conditions.

\section{Materials and methods}

\section{Sampling}

Thirty samples were collected in bottles reached their total volume $1000 \mathrm{ml}$ according to APHA (2005) at the end of December 2017 from Inlet of El-Bahr El-Saedy drinking water treatment plant, Rosetta Branch River Nile, Sidi-Salem, Kafr El-Sheikh Governorate, Egypt. Location of the studied area based on GPS information was done (Table 1). As well as, overview of the sampling site by GPS was recorded and a photo was taken as shown in Figure 1.

\section{Media}

For screening, isolation and enrichment of the microbial population, plate count agar media containing $5.0 \mathrm{~g}$ tryptone, $2.5 \mathrm{~g}$ yeast extracts, $1.0 \mathrm{~g}$ glucose, $9.0 \mathrm{~g}$ agar and $1.0 \mathrm{~L}$ reagent-grade water was used (APHA, 2005). Nutrient agar (NA) media (1 L; pH 6.3-6.8) contained $5.0 \mathrm{~g}$ peptone, $3.0 \mathrm{~g}$ beef extract and $15.0 \mathrm{~g}$ agar was also used for bacterial cultivation and purification after Vincent (1970). The shaking flask culture media namely Minimal Salt Broth (MSB) media containing different ammonia $\left(\mathrm{NH}_{3}\right)$ concentrations as a sole source of Nitrogen were used instead of $\left(\mathrm{NH}_{4}\right)_{2} \mathrm{SO}_{4}$ to determine efficiency of the tested three selected bacterial isolates in removing ammonia. MSB media containing $3.5 \mathrm{~g}$ $\mathrm{Na}_{2} \mathrm{HPO}_{4} .2 \mathrm{H}_{2} \mathrm{O}, 1.0 \mathrm{~g} \mathrm{KH} 2 \mathrm{PO}_{4}, 0.1 \mathrm{~g} \mathrm{MgCl}_{2} .6 \mathrm{H}_{2} \mathrm{O}, 0.05 \mathrm{~g} \mathrm{Ca}\left(\mathrm{NO}_{3}\right)_{2} .4 \mathrm{H}_{2} \mathrm{O}$ was added to the tested $\mathrm{NH}_{3}$ doses (Belal et al., 2017). For biochemical tests, different media were also used. To determine catalase activity, Mannitol Salt Agar media (MSA) containing $75.0 \mathrm{~g}$ 
$\mathrm{NaCl}, 10.0 \mathrm{~g}$ D-Mannitol, $0.025 \mathrm{~g}$ Phenol Red, $15.0 \mathrm{~g}$ agar as described by Gerhardt et al. (1981) were used. All media were autoclaved at $121^{\circ} \mathrm{C}$ for $30 \mathrm{~min}$ before use.

Table 1. Sampling site location of the studied drinking water treatment plant by GPS

\begin{tabular}{c|c|c}
\hline Treatment Plant (GPS) & X & Y \\
\hline El-Bahr El-Saedy & 281022.66 & 3463930.43 \\
\hline
\end{tabular}

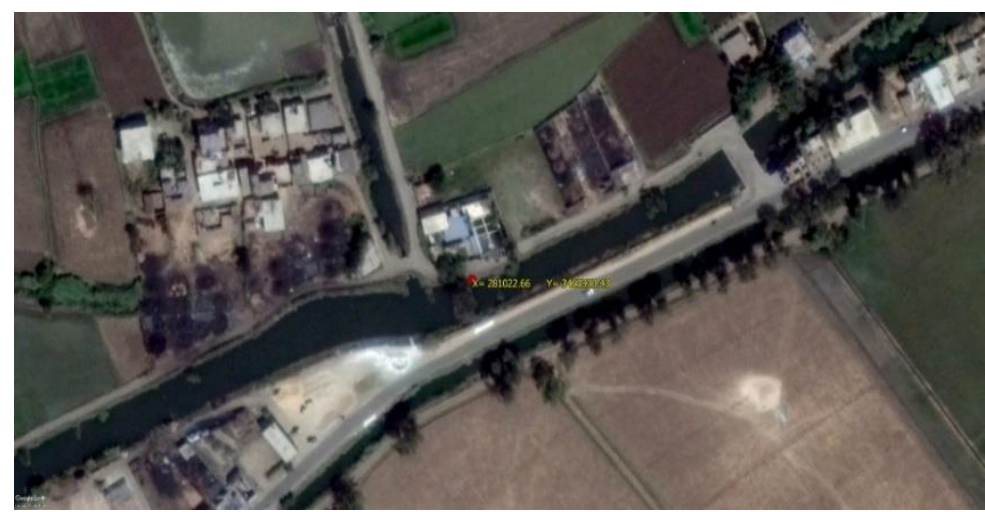

Figure 1. Sampling site location (inlet of El-Bahr El-Saedy drinking water treatment Plant, Rosetta Branch, Nile River)

\section{Isolation of ammonia-degrading bacteria}

Screening of the microbial population and isolation of ammonia-degrading bacteria from site El-Bahr El-Saedy drinking water treatment plant by cultivation on plate count agar media at $35 \pm 0.5^{\circ} \mathrm{C}$ for $48 \mathrm{~h}$ was done by enrichment technique. Bacterial isolates were purified on nutrient agar media using the standard spatial streaking method. Based on their morphological characteristics, ten isolates were transferred into Minimal salt broth (MSB) media containing $5 \mathrm{mg} \mathrm{L}^{-1}$ ammonia $\left(\mathrm{NH}_{3}\right)$ as a sole source of Nitrogen, instead of $\left(\mathrm{NH}_{4}\right)_{2}$ $\mathrm{SO}_{4}$ as in the preliminary test. Cultures were incubated at $35 \pm 0.5^{\circ} \mathrm{C}$ for 25 days. To detect their performance in degradation of ammonia, absorbance degree of the cultures was assayed by using spectrophotometer (CECIL of CECIL INSTRUMENTS, CAMBRIDGE, ENGLAND) at $420 \mathrm{~nm}$ as described by APHA (2005) and consumption rates were considered. Based on their preliminary test, three bacterial isolates (M.1, M.2 and M.3) were selected to evaluate their efficiency in removing ammonia in MSB media.

\section{Identification}

The efficient isolates were identified on the basis of morphological, cultural and biochemical characteristics. Data were optimized with those described based on Bergey's Manual of Systematic Bacteriology (1984) and then confirmed genetically using 16S rRNA by Boye et al. (1999). The molecular techniques were performed by sigma, Cairo, Egypt.

\section{Morphological, cultural and biochemical tests}

Samples were examined microscopically to investigate shape of cells, formation of endospores, gram staining reaction and motility. Starch hydrolysis, growth on $5 \% \mathrm{NaCl}$ and at $40^{\circ} \mathrm{C}$ were tested as recommended. Catalase activity was determined using a $3 \%$ 
$\mathrm{H}_{2} \mathrm{O}_{2}$ solution on MSA slant media as described by Gerhardt et al. (1981). Oxidase test was carried out by observing color change of trypticase soy agar (TSA) medium (containing 15.0 g Pancreatic Digest of Casein, 5.0 g Peptic Digest of Soybean Meal, $5.0 \mathrm{~g}$ Sodium Chloride, $15.0 \mathrm{~g}$ Agar) from pink to maroon and finally to purple within $30 \mathrm{sec}$ after adding 2-3 drops of 1\% of P-aminodimethyl aniline oxalate solution on the cultures (Cappuccino and Sherman, 1996). Urease test was performed on $5 \mathrm{ml}$ of urea broth $\left(20 \mathrm{~g} \mathrm{~L}^{-1}\right)$ (containing $20 \mathrm{~g}$ of urea, $9.5 \mathrm{~g}$ of $\mathrm{Na}_{2} \mathrm{HPO}_{4}, 9.1 \mathrm{~g}$ of $\mathrm{KH}_{2} \mathrm{PO}_{4}, 0.1 \mathrm{~g}$ of yeast extract) at $\mathrm{pH} 6.8$ in test tubes containing phenol red $\left(0.012 \mathrm{~g} \mathrm{~L}^{-1}\right)$ as the $\mathrm{pH}$ indicator. The cultures were transferred into the sterilized urea broth and incubated for $24 \mathrm{~h}$. The development of red color indicates a positive reaction for the test (Cappuccino and Sherman, 1996). Citrate utilization test was carried out by changing coloration of Simmons citrate agar medium (containing $5.0 \mathrm{NaCl}, 2.0$ g Sodium Citrate dehydrate, $1.0 \mathrm{~g}$ Ammonium Dihydrogen Phosphate) from green to blue due to $\mathrm{pH}$ change, which indicated positive reaction, according to Seeley and Vandemark (1981). To test indole production, isolates were inoculated into sterilized glucose tryptone broth (containing $2 \%(\mathrm{w} / \mathrm{v})$ tryptone, $0.5 \%(\mathrm{w} / \mathrm{v})$ yeast extract, $10 \mathrm{mM} \mathrm{NaCl}, 2.5 \mathrm{mM} \mathrm{KCl}, 10 \mathrm{mM}$ $\mathrm{MgCl}_{2}, 10 \mathrm{mM} \mathrm{MgSO}$, and $20 \mathrm{mM}$ glucose, $\mathrm{pH} \mathrm{7.0.)} \mathrm{in} \mathrm{test} \mathrm{tubes.} \mathrm{After} 48 \mathrm{~h}$ of incubation, $0.3 \mathrm{ml}$ of Kovac's reagent was added $(10 \mathrm{gm}$ of p-dimethyl aminobenzaldehyde were dissolved in $150 \mathrm{ml}$ of isoamylalcohol and then slowly $50 \mathrm{ml}$ of concentrated HCL were added) and mixed well. The reddening of the alcohol layer within few minutes indicated indole production (Seeley and Vandemark, 1981).

\section{S rRNA sequencing tests}

To confirm their identification, genomic 16S rRNA sequencing technique was carried out for the selected bacterial isolates. This technique was performed by Sigma, Cairo, Egypt and GATC Company, Germany. Genomic DNA of the tested bacterial antagonists was extracted according to use protocol of GeneJET ${ }^{\mathrm{TM}}$ genomic DNA purification Kit (Thermo K0721). The 16S rRNA gene was amplified through the recommended 37 thermal cycling conditions using Maxima Hot Start PCR (Polymerase Chain Reaction) Master Mix (Thermo K1051) according to Eden et al. (1991) were used. PCR reaction set-up ( $5 \mu \mathrm{L}$ DNA Template $+1 \mu \mathrm{l}(20 \mu \mathrm{M})$ Forward Primer $+1 \mu \mathrm{l}$ $(20 \mu \mathrm{M})$ Reverse Primers (of each 8 primers) $+25 \mu \mathrm{L}$ Maxima ${ }^{\circledR}$ Hot Start PCR Master Mix $(2 \mathrm{X})+18 \mu \mathrm{L}$ Nuclease Free Water) to complete total volume of $25 \mu \mathrm{L}$ was adjusted. Then, PCR products of $16 \mathrm{~S}$ rRNA using GeneJET ${ }^{\mathrm{TM}}$ PCR Purification Kit (Thermo K0701) were purified. PCR products were then sequenced and analyzed using ABI 3730x1 DNA sequencer via forward and reverse primers (GATC Company, Germany) by combining the traditional Sanger technology with the new 454 technology as follows:

\section{F: $5-$ AGA GTT TGA TCC TGG CTC AG -3 \\ R: $5-$ GGT TAC CTT GTT ACG ACT T - 3}

Phylogenetic analysis in MEGA6 was conducted (Tamura et al., 2013). For the phylogenetic analysis, maximum parsimony and neighbor-joining trees were constructed from 1000 bootstrap replicates.

\section{Cultivations}

As classical batch, cultivations of the selected three bacterial isolates on ammonia as a sole source of Nitrogen were carried out. Prior to the batch experiment, a studied 
substrate (ammonia, $\mathrm{NH}_{3}$ ) was added to the culture through a sterile Cellulose Nitrate filter membrane of $0.45 \mu \mathrm{m}$ (Sartorius Stedim, Biotech GmbH, 37070 Gottingen, Germany) by a syringe. All cultivations were carried out in flasks containing MSB media, with replacing $\mathrm{NH}_{3}$ instead of $\left(\mathrm{NH}_{4}\right)_{2} \mathrm{SO}_{4}$. The working volume was $200 \mathrm{ml}$. Cultures were supplied with 0.0, 5.0, 10.0 and $20.0 \mathrm{mg} \mathrm{L}^{-1}$ ammonia as a sole source of nitrogen for each isolate. All cultivations were carried out in three replicates. Cultures were shaking incubated on $150 \mathrm{rpm}$ at $35 \pm 0.5^{\circ} \mathrm{C}$ (Shaking Incubator, INCUCELL-V55, Einrichtungen GmbH, D-82166 Gräfelfing, Germany) for 25 days. After that, removing of ammonia was assayed in the incubated cultures by a spectrophotometer at $420 \mathrm{~nm}$ as described by APHA (2005) and substrate consumption rates at the tested substrate concentrations, $\mathrm{pH}$, temperature and ammonia concentrations were determined.

Based on a material balance for substrate (ammonia) in the batch cultivation, absolute substrate consumption rate $(R s)$ can be expressed as $\mathrm{mg} \mathrm{L}^{-1} \mathrm{day}^{-1}$ according to Shalaby (2007) and the modified equation of Curtis et al. (2018) as follows:

$$
\boldsymbol{r} \boldsymbol{s}=\frac{d C s}{d t}
$$

where:

$r \boldsymbol{s}$ - ammonia consumption rate $\left(\mathrm{mg} \mathrm{L}^{-1} \mathrm{day}^{-1}\right)$,

$d C s$ - difference between Initial ammonia and remaining ammonia concentrations $\left(\mathrm{mg} \mathrm{L}^{-1}\right)$,

$d t$ - difference between end and start incubation time (day).

\section{Effect of pH, temperature and ammonia concentrations on the biodegradation of ammonia}

To determine the effect of temperature, $\mathrm{pH}$ and ammonia concentrations on the biodegradation of ammonia, a volume of $200 \mathrm{ml} \mathrm{MSB}$ media containing $5.0 \mathrm{mg} \mathrm{L}^{-1}$ ammonia and inoculating with $1.0 \mathrm{ml}$ bacterial cell suspension $10^{5} \mathrm{CFU} \mathrm{ml^{-1 }}$. To determine the optimum $\mathrm{pH}$, experiments were carried out at $\mathrm{pH} 5.5,6.5,7.0,7.5$ and 8.0. Cultures were incubated on a rotary shaker at $35 \pm 0.5^{\circ} \mathrm{C}$ and $150 \mathrm{rpm}$ up to 25 days. To determine the effect of temperature, MSB media with pH 7.0 was incubated at 20, $25,30,32$ and $35^{\circ} \mathrm{C}$ under $150 \mathrm{rpm}$ for 25 days. To determine the effect of ammonia concentration, MSB media replaced their nitrogen source with 0.0, 5.0, 10.0 and 20.0 $\mathrm{mg} \mathrm{L}^{-1}$ ammonia adjusted their $\mathrm{pH}$ at 7.0 and incubated at $35 \pm 0.5^{\circ} \mathrm{C}$ under $150 \mathrm{rpm}$ for 25 days. Bioremediation of ammonia based on the absorbance measured by a spectrophotometer was determined and substrate consumption rate was calculated according to Shalaby (2007) and Curtis et al. (2018).

\section{Bioremediation of ammonia by mixtures of the tested bacterial isolates}

To test interaction behavior between them, antagonism test of the three bacterial isolates were inoculated in dual and in ternary bacterial mixtures in the same media as preliminary experiment. Nutrient agar (NA) media were liquefied, allowed to cool to about $45^{\circ} \mathrm{C}$, homogenized and inoculated with the initial test organism. These were then poured into sterile petri dishes and allowed to cool at room temperature before streaking with the second bacteria in the dual mixture or with the second and third bacteria in the 
ternary mixture. Observations and cultural relations were recorded $48 \mathrm{~h}$ after incubation of the plates at $37^{\circ} \mathrm{C}$ as described by Herbert et al. (2009).

Based on the observations of the antagonism test between the three isolates, applicability of the ternary bacterial mixtures in removal or degradation of ammonia was tested. To achieve the purpose mentioned, $1.0 \mathrm{ml}$ bacterial cell suspension containing $10^{5} \mathrm{CFU} \mathrm{ml}{ }^{-1}$ of each isolate was cultivated immediately with $200 \mathrm{ml}$ raw water from El-Bahr El-Saedy drinking water treatment plant in shake flasks containing $10.0 \mathrm{mg} \mathrm{L}^{-1}$ of ammonia. The cultures were shaking incubated under $150 \mathrm{rpm}$ at $35 \pm 0.5^{\circ} \mathrm{C}$ for $5.0,10.0,15.0,20.0$ and 25 days. Un-inoculated shake flasks were acted as control. The experiment was carried out in three replicates. Bioremediation of ammonia by the bacterial mixture was determined after the incubation period based on the absorbance measured by a spectrophotometer and substrate consumption rate was calculated according to the well-known formula of Shalaby (2007) and the modified equation of Curtis et al. (2018) previously used.

\section{Statistical analysis}

The statistical results were calculated by one-way analysis using the SPSS statistical software. A $P$-value $<0.05$ indicated statistical significance. The means were compared according to Duncan's multiple range test (Snedecor and Cochran, 1980).

\section{Results and discussion}

\section{Isolation of the ammonia-removing isolates}

From the microbial source (El-Bahr El-Saedy drinking water treatment plant) a total of 10 morphologically different ammonia-degrading bacterial isolates were obtained. Based on their efficiencies, three bacterial isolates designated as (M.1), (M.2) and (M.3) achieved higher ammonia consumption rates and were selected for further tests comparing with the other isolates, and the differences between treatment were significant at $P<0.05$ (Table 2).

\section{Identification of the ammonia-removing isolates}

Based on their cultural, morphological and biochemical properties, M.1, M.2 and M.3 isolates were identified as Bacillus aerius, Bacillus bingmayongensis and Bacillus toyonensis (Table 3). They were rods in shape, white color colonies, grampositive, motile, had positive ability to form endospores and grew on $5 \% \mathrm{NaCl}$. It was found also that all tested bacteria gave positive of oxidase, citrate utilization, catalase activity and starch hydrolysis. On the contrary, negative reactions of both urease and indole production were obtained.

Identification of such isolates was confirmed by using molecular genomic technique (Boye et al., 1999). According to the 16S rRNA analysis, the phylogenetic tree of the ammonia degrading Bacillus isolate (M.1) was done. It can be clearly seen that the M.1 Bacillus isolate was closely related to the species aerius. It showed the highest sequence similarities with Bacillus aerius strain 24K (76\%) (Figure 2).

Although Falsibacillus pallidus strain has ident (77\%), the identification confirms that the tested isolate belongs to Bacillus aerius (76\%) based on total score of it (315) in comparison with total score of Falsibacillus pallidus (280). As well as, the second isolate (M.2) was found to be included in the genus Bacillus and closely related to the 
species bingmayogensis. It showed the highest sequence similarities with Bacillus bingmayongensis strain FJAT-13831 (89\%) (Figure 3). Although all strains have the same ident (89\%), the identification confirms that the tested isolate belongs to Bacillus bingmayongensis based on total score of it (547) which is higher total score than that of other strains.

Table 2. Ammonia consumption rates of 10 bacterial isolates cultivated in MSB media under batch conditions

\begin{tabular}{c|c}
\hline Isolate & $\begin{array}{c}\text { Ammonia consumption rate } \\
\left(\mathbf{m g ~ L}^{-1} \text { day }^{-1}\right)\end{array}$ \\
\hline M.1 & $0.206 \mathrm{a}$ \\
M.2 & $0.197 \mathrm{c}$ \\
M.3 & $0.202 \mathrm{~b}$ \\
M.4 & $0.012 \mathrm{i}$ \\
M.5 & $0.070 \mathrm{~d}$ \\
M.6 & $0.020 \mathrm{fg}$ \\
M.8 & $0.015 \mathrm{hi}$ \\
M.9 & $0.035 \mathrm{e}$ \\
M.10 & $0.017 \mathrm{gh}$ \\
\hline
\end{tabular}

Ammonia consumption rate followed by different letters within a column are significantly different at $(P<0.05)$, Duncan's multiple range test

Table 3. Morphological, cultural and some biochemical characteristics of the three bacterial isolates coded as M.1, M.2 and M.3

\begin{tabular}{c|c|c|c}
\hline Characteristics & M.1 & M.2 & M.3 \\
\hline Shape of cell & Rods & Rods & Rods \\
Formation of endospore & + & + & + \\
Motility & + & + & + \\
Gram reaction & + & + & + \\
Growth on $5 \% \mathrm{NaCl}$ & + & + & + \\
Growth at $40{ }^{\circ} \mathrm{C}$ & - & + & + \\
Starch hydrolysis & + & + & + \\
Catalase reaction & + & + & + \\
Oxidase test & + & - & + \\
Urease test & - & + & - \\
Citrate utilization & + & - & + \\
Indole production & - & &
\end{tabular}

+ Positive; - Negative

For the third isolate (M.3), it was found that it also belonged to genus Bacillus and was closely related to the species toyonensis. It showed the highest sequence similarities with Bacillus toyonensis strain BCT-7112 (99\%) (Figure 4). Although all strains have the same ident (99\%), the identification confirms that the tested isolate belongs to Bacillus toyonensis based on total score of it (1437) which is a higher total score than in other strains.

As well as, results recorded in Figure 5 showed that 1500 bp DNA fragment was obtained by PCR amplification of the 16S rRNA gene of the three tested Bacillus isolates. 


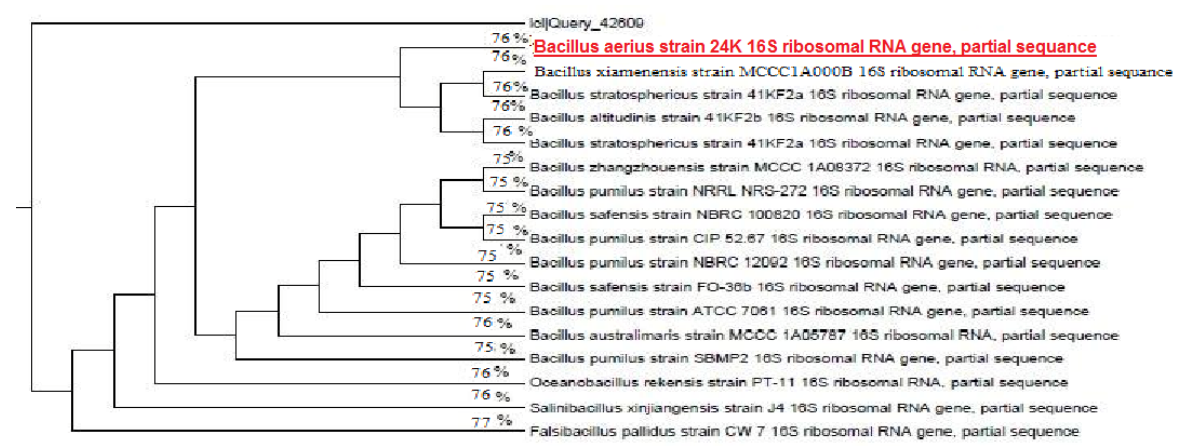

Figure 2. The phylogenetic tree of the ammonia-degrading bacterium isolate M.1 was identified as Bacillus aerius

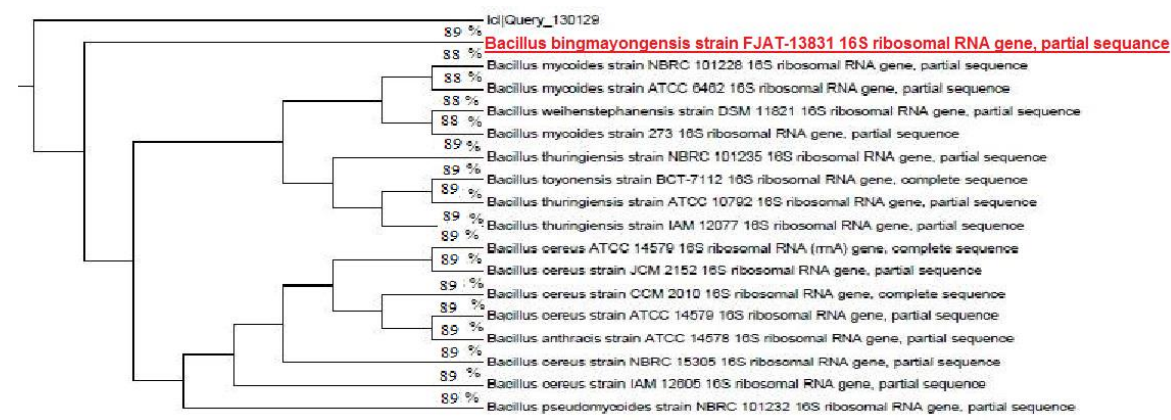

Figure 3. The phylogenetic tree of the ammonia-degrading bacterium isolate M.2 was identified as Bacillus bingmayongensis (M.2)

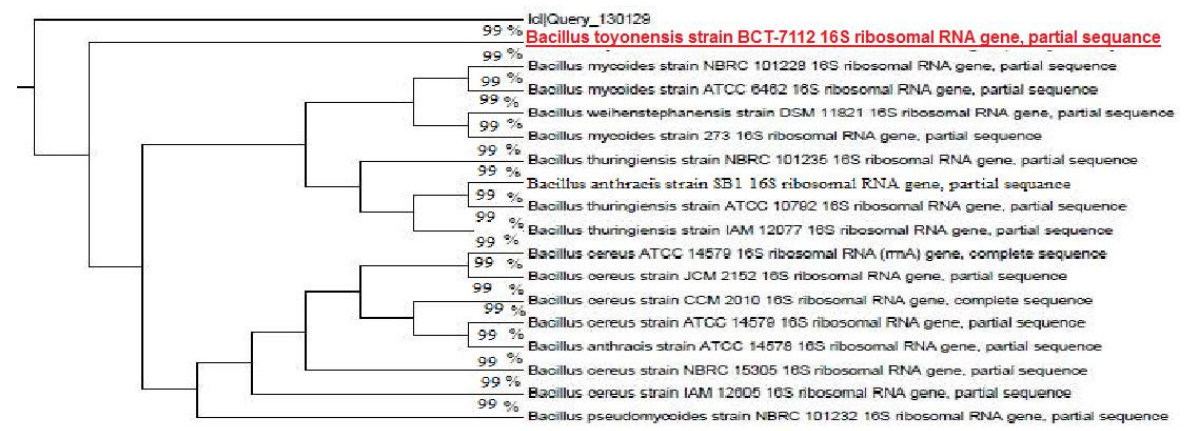

Figure 4. The phylogenetic tree of the ammonia-degrading bacterium isolate M.3 was identified as Bacillus toyonensis (M.3)

Isolation of such ammonia-degrading Bacillus isolates from the studied aquatic inlet site on Rosetta branch, River Nile indicated high capacity and variation of the microbial populations. It was in full agreement with Belal et al. (2017), who isolated Ralstonia pickettii (ST.1) and Chryseobacterium gambrini (ST.2) from River Nile during increasing ammonia concentration and identified it morphologically using enrichment technique then molecularly using 16S rDNA gene. While Kundu et al. (2014) pointed that Chryseobacterium gambrini is capable of simultaneous removal of organic carbon and nitrogen from wastewater. 


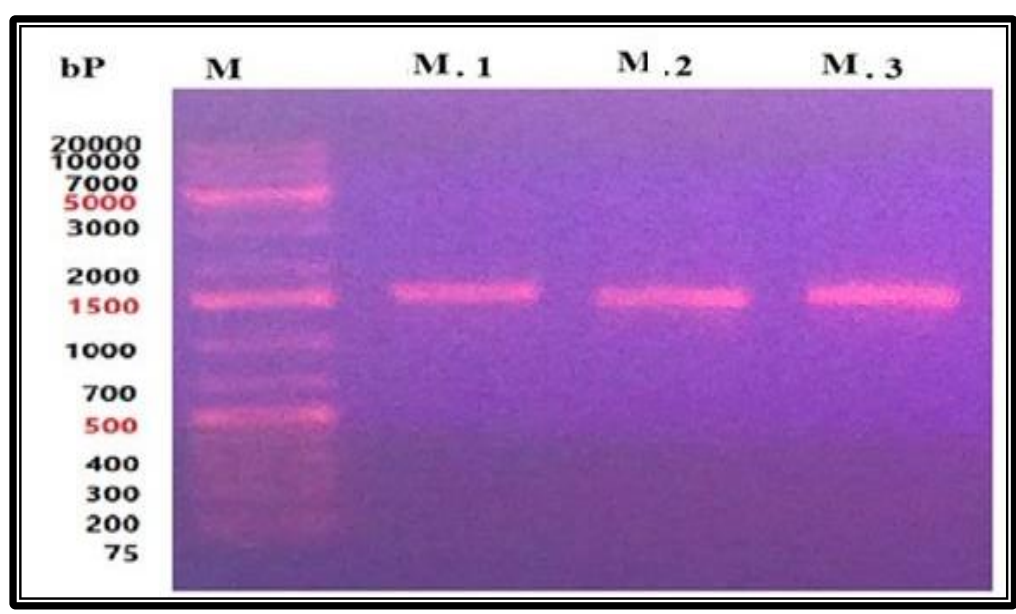

Figure 5. Agarose gel electrophoresis showing $16 S$ rRNA sequencing patterns of the three tested Bacillus isolates. M: marker, M.1: Bacillus aerius, M.2: bingmayongensis and M.3: Bacillus toyonensis

\section{Effect of $\mathrm{pH}$ and temperature on the biodegradation of ammonia Effect of $p H$}

Influence of $\mathrm{pH}$ on ammonia consumption rate in cultures inoculated separately with B. aerius (M.1), B. bingmayongensis (M.2) and B. toyonensis (M.3) each was obtained and presented in Table 4. Results indicated that $\mathrm{pH}$ values of 6.5 and 7.0 were the most suitable range for removing ammonia by the three tested isolates. On the other hand, no consumption of ammonia in the control cultures free from any biomass was noticed, indicating no chemical degradation. For B. aerius (M.1) and B. toyonensis (M.3), the highest consumption rates of 0.160 and $0.157 \mathrm{mg} \mathrm{L}^{-1}$ day $^{-1}$ at $\mathrm{pH} 6.5$ was achieved. in the case of B. aerius (M.1), the differences between treatment are significant at $P<0.05$, as well as in the case of B. toyonensis (M.3) at $\mathrm{pH}$ values $6.5,7.5$ and 8 , the differences between treatments are significant at $P<0.05$, but at $\mathrm{pH}$ values 5.5 and 7 , the differences between treatments are not significant.

Table 4. Effect of different $p H$ values on ammonia consumption rates by B. aerius (M.1), B. bingmayongensis (M.2) and B. toyonensis (M.3) under batch culture conditions

\begin{tabular}{c|c|c|c|c}
\hline \multirow{2}{*}{$\mathbf{p H}$} & \multicolumn{4}{|c}{ Ammonia consumption rate $\left(\mathbf{m g ~ L}^{-\mathbf{1}}\right.$ day $\left.^{-1}\right)$} \\
\cline { 2 - 5 } & Control & $\begin{array}{c}\text { B. aerius } \\
\text { (M.1) }\end{array}$ & $\begin{array}{c}\text { B. bingmayongensis } \\
\text { (M.2) }\end{array}$ & $\begin{array}{c}\text { B. toyonensis } \\
\text { (M.3) }\end{array}$ \\
\hline 5.5 & 00.0 & $0.143 \mathrm{~b}$ & $0.114 \mathrm{e}$ & $0.138 \mathrm{~b}$ \\
6.5 & 00.0 & $0.160 \mathrm{a}$ & $0.136 \mathrm{~b}$ & $0.157 \mathrm{a}$ \\
7.0 & 00.0 & $0.130 \mathrm{c}$ & $0.158 \mathrm{a}$ & $0.140 \mathrm{~b}$ \\
7.5 & 00.0 & $0.120 \mathrm{~d}$ & $0.130 \mathrm{c}$ & $0.110 \mathrm{c}$ \\
8.0 & 00.0 & $0.118 \mathrm{e}$ & $0.124 \mathrm{~d}$ & $0.100 \mathrm{~d}$ \\
\hline
\end{tabular}

It was in full agreement with Shafi et al. (2017), who suggested that the $\mathrm{pH}$ value has a critical role in the production of secondary metabolites and that its maintenance at medium levels is optimal for neutrophils such as $B$. aerius and confirmed that activity achieved at range $\mathrm{pH}$ 4-10 and the highest activity for bioremediation was observed at 
pH 6.5. As well as, Tallur et al. (2016) confirmed that B. toyonensis (PNTB1) can grow at $\mathrm{pH}$ ranged between $5.5-10.0$ and its optimal value at $\mathrm{pH} 7.1$ was obtained. While, the highest consumption rate due to use of B. bingmayongensis (M.2) was achieved at $\mathrm{pH} 7.0$, and the differences between treatments are significant at $P<0.05$. Such result was given by Liu et al. (2014). They reported that B. bingmayongensis can grow at $\mathrm{pH}$ ranged between $4.0-10.0$ and its optimal value was recorded at $\mathrm{pH} 7.0$.

\section{Effect of temperature}

Influence of temperature degrees on ammonia consumption rate in cultures inoculated separately with B. aerius (M.1), B. bingmayongensis (M.2) and B. toyonensis (M.3) each was obtained and presented in Table 5. Data illustrated that temperature degrees of 30,32 and $35^{\circ} \mathrm{C}$ were the most optimal for removing ammonia by the three tested isolates. On the other hand, no consumption of ammonia in the control cultures was noticed, indicating no chemical degradation. In the case of B. aerius (M.1), the optimal temperature degree recorded for ammonia bioremediation was $32^{\circ} \mathrm{C}$, at which ammonia consumption rate to its maximum of $0.168 \mathrm{mg} \mathrm{L}^{-1} \mathrm{day}^{-1}$ was reached, and the differences between treatments are significant at $P<0.05$. This result was in full agreement with Shafi et al. (2017), who confirmed that $B$. aerius can grow at temperature ranging between 8.0 and $40.0^{\circ} \mathrm{C}$ and the optimal was reached at $32^{\circ} \mathrm{C}$ under the experimental conditions. For B. bingmayongensis (M.2), the corresponding optimal temperature degree at $30^{\circ} \mathrm{C}$ was done and ammonia consumption rate of $0.164 \mathrm{mg} \mathrm{L}^{-}$ ${ }^{1}$ day $^{-1}$ were given, but the differences between treatments are not significant.

Table 5. Effect of different temperature degrees on ammonia consumption rates by $B$. aerius (M.1), B. bingmayongensis (M.2) and B. toyonensis (M.3) under batch culture conditions

\begin{tabular}{c|c|c|c|c}
\hline \multirow{2}{*}{ Temp. $\left({ }^{\circ} \mathbf{C}\right)$} & \multicolumn{4}{|c}{ Ammonia consumption rate $\left(\mathbf{m g ~ L}^{\mathbf{1}}\right.$ day $\left.^{-\mathbf{1}}\right)$} \\
\cline { 2 - 5 } & Control & $\begin{array}{c}\text { B. aerius } \\
\text { (M.1) }\end{array}$ & $\begin{array}{c}\text { B. bingmayongensis } \\
\text { (M.2) }\end{array}$ & $\begin{array}{c}\text { B. toyonensis } \\
(\text { M.3) }\end{array}$ \\
\hline 20 & 00.0 & $0.116 \mathrm{e}$ & 0.132 & $0.124 \mathrm{e}$ \\
25 & 00.0 & $0.130 \mathrm{~d}$ & 0.148 & $0.138 \mathrm{~d}$ \\
30 & 00.0 & $0.158 \mathrm{~b}$ & 0.164 & $0.150 \mathrm{c}$ \\
32 & 00.0 & $0.168 \mathrm{a}$ & 0.140 & $0.156 \mathrm{~b}$ \\
35 & 00.0 & $0.156 \mathrm{c}$ & 0.130 & $0.168 \mathrm{a}$ \\
\hline
\end{tabular}

Temp. $\left({ }^{\circ} \mathrm{C}\right)$ : Temperature

Liu et al. (2014) agreed with these results and stated that B. bingmayongensis can be grown very well at range varied between 15.0 and $45.0^{\circ} \mathrm{C}$ and $30.0^{\circ} \mathrm{C}$ was the optimum. On the other hand, B. toyonensis (M.3) was the most thermo-tolerant isolate in comparison with the others; by its ammonia consumption rate reached to its maximum of $0.164 \mathrm{mg} \mathrm{L}^{-1} \mathrm{day}^{-1}$ at $35.0^{\circ} \mathrm{C}$, and the differences between treatments are significant at $P<0.05$. These results agreed by Tallur et al. (2016), who confirmed that $B$. toyonensis (PNTB1) has a great ability to grow at temperature range between 10.0 and $45.0^{\circ} \mathrm{C}$ and its optimum degree is $37.0^{\circ} \mathrm{C}$.

\section{Effect of ammonia concentrations}

To investigate the effect of high ammonia concentrations accumulated in the aquatic system on the microbial activity and their ability to remove the excess of its doses, 
relationship between ammonia concentrations and its consumption rates by the tested isolates were recorded in Table 6. Results illustrated increase in ammonia consumption rates by increasing its concentration in the cultivation media due to the tested bacterial isolates, indicating growth activation and no substrate limitation. It seems to note that substrate consumption rates at both 5.0 and $10.0 \mathrm{mg} \mathrm{L}^{-1}$ ammonia were found to be identical and located at similar line for all isolates. At $20.0 \mathrm{mg} \mathrm{L}^{-1}$, efficiencies of the three isolates in removing ammonia varied. The greatest ability to overcome and remove the excess of ammonia concentrations $\left(20.0 \mathrm{mg} \mathrm{L}^{-1}\right)$ was obtained by the superior isolate B. toyonensis (M.3), by which its consumption rate to its maximum of $0.684 \mathrm{mg} \mathrm{L}^{-1} \mathrm{day}^{-1}$ was reached. It was followed by B. bingmayongensis (M.2) and B. aerius (M.1), by which consumption rates of ammonia to 0.635 and $0.595 \mathrm{mg} \mathrm{L}^{-}$ ${ }^{1}$ day $^{-1}$ at the highest dose were obtained, respectively. On the other hand, no ammonia was consumed in control cultures, indicating no chemical degradation, and the differences between treatments are significant at $P<0.05$. These results were in agreement with Leejeerajumnean et al. (2000), who found that bacteria particularly sensitive to ammonia (inhibited by $25 \mathrm{mmol} \mathrm{l}^{-1}$ ) or specially tolerant to ammonia (growth in the presence of $300 \mathrm{mmol} \mathrm{l}^{-1}$ ) included both Gram-positive and Gramnegative strains and there was no evidence for sensitivity or tolerance being associated with any specific bacterial genera.

Table 6. Effect of different ammonia concentrations on its consumption rates by B. aerius (M.1), B. bingmayongensis (M.2) and B. toyonensis (M.3) under batch culture conditions

\begin{tabular}{c|c|c|c|c}
\hline $\begin{array}{c}\text { Ammonia } \\
\begin{array}{c}\text { concentration } \\
\left(\mathbf{m g ~ L}^{-1}\right)\end{array}\end{array}$ & Control & $\begin{array}{c}\text { B. aerius } \\
\text { (M.1) }\end{array}$ & $\begin{array}{c}\text { B. bingmayongensis } \\
(\text { M.2) }\end{array}$ & $\begin{array}{c}\text { B. toyonensis } \\
(\text { M.3 })\end{array}$ \\
\cline { 2 - 5 } & 0.0 & $0.000 \mathrm{~d}$ & $0.000 \mathrm{~d}$ & $0.000 \mathrm{~d}$ \\
0.0 & 0.0 & $0.206 \mathrm{c}$ & $0.197 \mathrm{c}$ & $0.202 \mathrm{c}$ \\
5.0 & 0.0 & $0.364 \mathrm{~b}$ & $0.351 \mathrm{~b}$ & $0.359 \mathrm{~b}$ \\
10.0 & 0.0 & $0.595 \mathrm{a}$ & $0.635 \mathrm{a}$ & $0.684 \mathrm{a}$ \\
20.0 & \multicolumn{4}{c}{}
\end{tabular}

\section{Bioremediation of ammonia by mixtures of the tested bacterial isolates}

One of the major problems of the biological degradation of environmental pollutants in an aquatic environment is the co-existence of substrate compounds or/and microbial mixtures. In the aquatic ecosystems, the microorganisms grow under complex conditions. Therefore, occurrence of the microbes in mixtures is an important problem, because removal or degradation of one component by a microbe can be prevented or inhibited by the other microbe in the mixture, and different conditions may be required.

Accordingly, and based on their cultural observations, growth and microbial relations, results showed no antagonistic reaction between isolates B. aerius (M.1), B. bingmayongensis (M.2) and B. toyonensis (M.3) in both dual and ternary culture mixtures. Microbes of the tested cultural mixtures were in their normal states without any disorders, disruption or competition between each other. Microbe may compete with another microbe for place or nutrients. Competitions often led to inhibit growth of the other microbe(s) in the same media via production of toxic metabolites, indicating antagonistic effect (Talaro et al., 2002).

Based on the results of antagonism test, efficiency of the ternary bacterial mixture composed of B. aerius (M.1), B. bingmayongensis (M.2) and B. toyonensis (M.3) in 
removal or degradation of $10.0 \mathrm{mg} \mathrm{L}^{-1}$ ammonia in MSB media free from any other nitrogen source at $35 \pm 0.5^{\circ} \mathrm{C}$ for different incubation periods was evaluated (Figure 6 ).

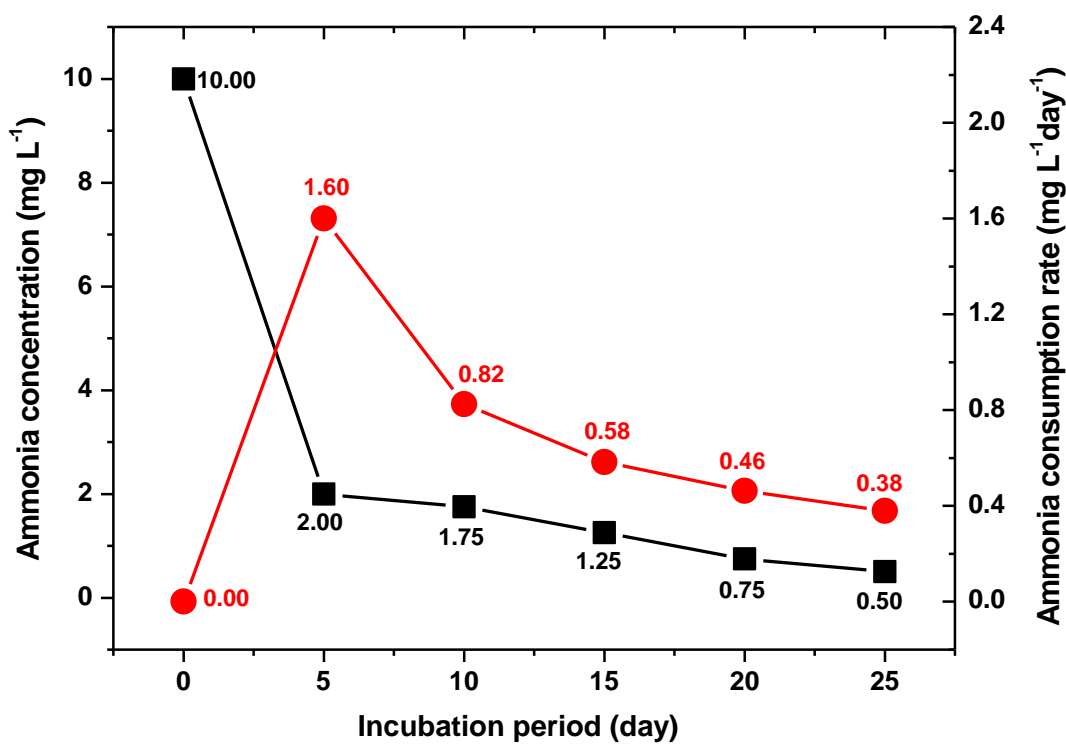

Figure 6. Remaining ammonia concentrations and their consumption rates by ternary bacterial mixtures composed of B. aerius (M.1), B. bingmayongensis (M.2) and B. toyonensis (M.3) at $35 \pm 0.5^{\circ} \mathrm{C}$ for different incubation periods. Curve with different letters are significantly different at 0.05 level based on Duncan's multiple range test

Results showed sharp reduction of ammonia concentration by the ternary bacterial mixture five days after incubation from 10.0 to $2.0 \mathrm{mg} \mathrm{L}^{-1}$, and consumption rate to its maximum of $1.60 \mathrm{mg} \mathrm{L}{ }^{-1} \mathrm{day}^{-1}$ was reached, and then reduced slowly. After 25 incubation days, only $0.50 \mathrm{mg} \mathrm{L}^{-1}$ of ammonia were remained and its consumption to its minimal rate of $0.38 \mathrm{mg} \mathrm{L}^{-1} \mathrm{day}^{-1}$ was given, and the differences between treatments were significant at $P<0.05$. These results were in agreement with the findings of Hemida et al. (2018), who reported that the co-inoculation of the two selected endophytic bacteria strains B. aerius (M.1) and B. toyonensis could successfully enhance salt tolerance and nitrogen fixation, ammonia utilization, inorganic phosphate solubilization. To investigate ammonia utilization pattern by the ternary mixture (simultaneous or sequential), its consumption rates by the individual isolates were compared with those obtained by the ternary mixture. In the presence of $10 \mathrm{mg} \mathrm{L}^{-1}$ ammonia, its consumption rate reached to $0.46 \mathrm{mg} \mathrm{L}^{-1}$ day $^{-1}$ by the ternary mixture 20.0 days after incubation, compared with $0.36,0.35$ and $0.36 \mathrm{mg} \mathrm{L}^{-1}$ day $^{-1}$ by single isolates of B. aerius (M.1), B. bingmayongensis (M.2) and B. toyonensis (M.3), respectively. It means increasing efficiency of the ternary mixture in removing ammonia compared with the individual treatment. So, ammonia utilization pattern by the ternary bacterial mixture was sequential, indicating activation not antagonism between isolates in the ternary mixture.

\section{Conclusion}

From the obtained results it can be concluded that the cultivation of a ternary tested bacterial mixture of ammonia can be expressed by substrate consumption rates obtained 
from the individually cultivations. In general, it can be stated that the removal of different ammonia concentrations from the aquatic systems was successfully done via both individual and ternary mixture composed of B. aerius (M.1), B. bingmayongensis (M.2) and B. toyonensis (M.3) under static batch cultivation.

We must keep River Nile as a sole source of drinking water in Egypt healthy. Complete optimization of such tested bacterial isolates used successfully for removing pollutants of aquatic systems, especially at a temperature range more than $35^{\circ} \mathrm{C}$ and high concentrations of ammonia more than $20 \mathrm{mg} \mathrm{L}^{-1}$ is necessary in the future.

Acknowledgments. The author highly acknowledges, Agriculture Botany Department, Fac. of Agric., Kafr El-sheikh Univ., Kafr El-Sheikh, Egypt; water and wastewater Company, Main laboratory of Sidi Salem city, Kafr El-sheikh, Egypt.

\section{REFERENCES}

[1] Abdel-Satar, A. M., Ali, M. H., Goher, M. E. (2017): Indices of water quality and metal pollution of Nile River, Egypt. - The Egyptian Journal of Aquatic Research 43(1): 21-29.

[2] Abou-Elela, S. I. (2017): Constructed Wetlands: The Green Technology for Municipal Wastewater Treatment and Reuse in Agriculture. - Unconventional water Resources and agriculture in Egypt: 1-51.

[3] Al-Rashedy, A. H., Youssef, R. A., Farfour, S. A., Mousa, I. E. (2018): Seasonal Variation Of Water Resources And Its Suitability For Drinking Water Production. - The 9th Int. Conf. for Develop. and the Env. in the Arab world: 15-17.

[4] APHA. (2005): Standard methods for the examination of water and waste water, 21 st ed. - American Public Health Association, Washington, D.C.

[5] Belal, E. B., Shalaby, M. E., El-Khateeb, N. M., Maksoud, Y. M. A., Gad, M. A. (2017): Bioremediation of ammonia in river Nile by Ralstonia pickettii and Chryseobacterium gambrini. - Research Journal of Pharmaceutical, Biological and Chemical Sciences (RJPBCS) 8(3): 497-505.

[6] Bergey, D. H., Holt, J. G., Krieg, N. R., Sneath, P. H. A., Mair, N. S., Sharpe, M. E., Williams, S. T. (1984): Bergey's manual of systematic bacteriology. - Williams and Wilkins, Baltimore, USA.

[7] Boye, K., Høgdall, E., Borre, M. (1999): Identification of bacteria using two degenerate 16S rDNA sequencing primers. - Microbiological research 154(1): 23-26.

[8] Cappuccino, J. G., Sherman, N. (1996): In Microbiology: A Laboratory Manual. - The Benjamin/Cunnings Publishing Company Inc. (4 ${ }^{\text {th }}$ Edition), Menlopark, California, USA.

[9] Curtis, B., Giorgi, S., Buffone, A. E., Ungar, L. H., Ashford, R. D., Hemmons, J., Schwartz, H. A. (2018): Can Twitter be used to predict county excessive alcohol consumption rates? - PLoS One 13(4): e0194290.

[10] Eden, P. A., Schmidt, T. M., Blakemore, R. P., Pace, N. R. (1991): Phylogenetic analysis of Aquaspirillum magnetotacticum using polymerase chain reaction-amplified $16 \mathrm{~S}$ rRNA-specific DNA. - International Journal of Systematic and Evolutionary Microbiology 41(2): 324-325.

[11] Fawzy, M. A., Badr, N. E. S., El-Khatib, A., Abo-El-Kassem, A. (2012): Heavy metal biomonitoring and phytoremediation potentialities of aquatic macrophytes in River Nile. - Environmental monitoring and assessment 184(3): 1753-1771.

[12] Gerhardt, P., Murray, R. G. E., Costilow, R. N., Nester, E. W., Wood, W. A., Krieg, N. R., Phillips, G. B. (1981): Manual of methods for general bacteriology. - Washington, D.C., American Society for Microbiology. 
[13] Hemida, K. A., Reyad, A. M. (2018): Improvement salt tolerance of safflower plants by endophytic bacteria. - J Hortic Plant Res 5: 38-56.

[14] Herbert, J., Santos, D., Jefty, J. R., Garcera, A., Zuniega, R. R. (2009): Synergistic and Antagonistic Relationships of Escherechia coli, Bacillus cereus, Bacillus subtilis, Staphylococcus aureus and Penicilliumnotatum, BIO120. - General Microbiology (Laboratory).

[15] Holmes, D. E., Dang, Y., Smith, J. A. (2019): Nitrogen cycling during wastewater treatment. - Advances in applied microbiology 106: 113

[16] Ibrahim, M., Al-Zyoud, S., Elhaddad, E. (2018): Surface Water Quality Monitoring for River Nile, Egypt Using GIS-Techniques. - Open Journal of Geology 8(02): 161.

[17] Kundu, P., Pramanik, A., Dasgupta, A., Mukherjee, S., Mukherjee, J. (2014): Simultaneous heterotrophic nitrification and aerobic denitrification by Chryseobacterium sp. R31 isolated from abattoir wastewater. - BioMed research international: 1-12.

[18] Leejeerajumnean, A., Ames, J. M., Owens, J. D. (2000): Effect of ammonia on the growth of Bacillus species and some other bacteria. - Letters in applied microbiology 30(5): 385-389.

[19] Liu, B., Liu, G. H., Hu, G. P., Cetin, S., Lin, N. Q., Tang, J. Y., Lin, Y. Z. (2014): Bacillus bingmayongensis sp. nov., isolated from the pit soil of Emperor Qin's Terracotta warriors in China. - Antonie Van Leeuwenhoek 105(3): 501-510.

[20] Nieder, R., Dinesh, K. B., Franz, X. R. (2018): Reactive Water-Soluble Forms of Nitrogen and Phosphorus and Their Impacts on Environment and Human Health. - Soil Components and Human Health. Springer, Dordrecht: 223-255.

[21] Seeley, H. W., Van Demark, P. J. (1981): Microbes in Action. - Laboratory Manual of Microbiology, 3rd Ed, WH Freeman and Company USA.6.

[22] Shafi, J., Mingshan, J., Zhiqiu, Q., Xiuwei, L., Zumin, G., Xinghai, L., Kai, W. (2017): Optimization of Bacillus aerius strain JS-786 cell dry mass and its antifungal activity against Botrytis cinerea using response surface methodology. - Archives of Biological Sciences 69(3): 469-480.

[23] Shalaby, M. E. (2007): Kinetics of phenol and benzoate biodegradation in static cultivation system by Burkholderia cepacia G4. J. - Agric. Sci. Mansoura Univ. 32(4): 3007-3019.

[24] Snedecor, G. W., Cochran, W. G. (1980): Statistical methods. $7^{\text {th }}$ Ed. - Iowa State Univ. press, Ames, Iowa.

[25] Talaro, K. P., Talaro, A. (2002): Foundations in Microbiology 4th Edition. - Mc Graw Hill Publishing, USA.

[26] Tallur, P. N., Sajjan, D. B., Mulla, S. I., Talwar, M. P., Pragasam, A., Nayak, V. M., Bhat, S. S. (2016): Characterization of antibiotic resistant and enzyme producing bacterial strains isolated from the Arabian Sea. - 3 Biotech 6(1): 28.

[27] Tamura, K., Stecher, G., Peterson, D., Filipski, A., Kumar, S. (2013): MEGA6: molecular evolutionary genetics analysis version 6.0. - Molecular biology and evolution 30(12): 2725-2729.

[28] Vincent, J. M. (1970): A manual for the practical study of root-nodule bacteria. - IBP handbook, Blackwell Scientific Publications, Oxford and Edinburgh 15: 54-58.

[29] WHO. (2006): Guidelines for the Safe Use of Wastewater, Excreta and Greywater: Policy and regulatory aspects. - World Health Organization.

[30] Zenhom, S. E., Elsaiedy, G., El-Nahrawy, A. (2017): Assessment of the Groundwater Quality for Drinking and Irrigation Purposes in the Central Nile Delta Region, Egypt. Groundwater in the Nile Delta: 1-38. 